\title{
Role of Micro-credit in Poverty Alleviation of Rural Poor: Evidence from Laxmipur District of Bangladesh
}

\author{
MD. REZAUL KARIM* \\ SHAMSUNNAHAR TANIA** \\ MD. MANZUR RAHMAN FARAZI***
}

\begin{abstract}
This paper examines the role of microcredit as a tool to fight poverty. Bangladesh Government and Non-Government Organizations (NGOs) have been trying to alleviate poverty of its people. NGOs provide microcredit to poor people to enhance their income and improve the situation of hardship. This study takes up the Laxmipur experience of Bangladesh. The study reveals that microcredit programs have generated positive results for large numbers of the poor. Micro-credit has significant impacts and ensures the food security. The poor are not homogeneous, so impact varies significantly among different segments of the population according to their socio-economic status, gender, background, family composition and others. The analysis shows that in general, the poorest borrowers benefit less compared to the middle level poor. Microcredit is not the only way out for all the poor for alleviating their poverty. Our analysis shows that microcredit alone cannot alleviate the poverty significantly without ensuring their individual transactional powers such as economic transaction, social transaction, legal transaction and political transaction power.
\end{abstract}

Key words: poverty alleviation, individual transactional power, microcredit, food security.

\section{INTRODUCTION}

\section{Poverty}

Poverty is a situation of lack of the usual or socially acceptable amount of money or material possessions (Michael 2004). Poverty is a problem for all the countries irrespective of their level of development. It may be a lack of income or resources, a lack of coping capacity, a lack of basic human capabilities, a lack of institutional defenses or in extreme cases a lack of all these.

\footnotetext{
*Assistant Professor, Department of Statistics, Jahangirnagar University, Savar, Dhaka.

**Assistant Professor, Department of Business Administration (Marketing), Stamford University Bangladesh, Dhaka.

***Assistant Professor, Department of Statistics, Jahangirnagar University, Savar, Dhaka.
} 
In a wider sense, it may be a combination of economic, social and political deprivations. It means not having enough to feed and clothe a family, not having a school or clinic to go, not having the land on which to grow one's food or a job to earn one's living, not having access to credit. It means insecurity, powerlessness and exclusion of individuals, households and communities (Gordon, D. 2011).

\section{Microcredit}

Microcredit programs extend small loans to the very poor people for selfemployment projects that generate income, allowing them to care for themselves and their families. Microcredit also called "microfinance" and "microlending" means providing small working capital loans to the self-employed people. Even small amounts of capital can make the difference between absolute poverty and a thriving little business generating enough income to feed the family, send kids to school, and build decent housing. Micro-credit refers to programs that are poverty focused and that provide financial and business services to the very poor people for generation of self-employment and income. Credit is a powerful instrument to fight against poverty. The role of micro-credit in reducing poverty is now well recognized all over the world. Governments, donors, development agencies, banks, universities, consultants, philanthropists and others have increasing interest in it.

The universal objective of microfinance is to make it possible for large numbers of low-income people to access institutional financial services, hence the potential benefits of microfinance has accounted for its widespread adoption as an economic development, job creation and poverty reduction strategy. There is an on-going debate whether credit alone or credit plus is needed for poverty reduction. There are views that credit alone on its own is inadequate to fight against poverty. The need for other services is also important in this respect. Such views, although, do not negate the role of credit; fail to appreciate the role of credit on its own merit.

\section{Objective of the Research}

This research is aimed at investigating the livelihood of the rural poor and the role of microcredit in poverty alleviation of rural poor in case ofLaxmipur district, Bangladesh. Thevarious transaction powers are economic, social, legal, political and facilities factor from the State. Our main assumption is "poverty is significantly related with individual powers of these transactions". By this 
research, indirectly we will try to justify this assumption as well as the following specific objectives:

i) To investigate the livelihood characteristics and deprivation of the rural poor in the study area.

ii) To investigate the impact of microcredit in the improvement of different hardship indicators of rural poor in Laxmipur district, Bangladesh.

The rest of the paper is organized as: section 2 contains a brief review of the related studies; section 3 describes the methodology used in this article. The next section presents the empirical results of the data analysis. Section 5 focuses on some concluding remarks.

\section{LITERATURE REVIEW}

In this section a review of literature on different aspects of micro-credit programs has been made. It is needless to say that micro-credit helps the poor in day-to-day household-level consumption of basic necessities as well as in asset building. It also promotes investment in human capital like schooling. It raises awareness to reproductive health and increases both individual and household welfare.

Microcredit programs have also, in many cases, increased mobility and strengthened networks among women who were previously confined to the home (Carr et al. 1996). Borrowers build solidarity through their participation in lending circles and village organizations. This is especially important in Bangladesh, for example, where women's mobility is limited, and weekly meetings can be an opportunity for women to meet outside the home and discuss their problems. There are also studies that suggest even more far-reaching social impact, including decreases in fertility rates, assumed to be linked to increased financial self-reliance and more say for women in family matters, including family finances (Hashemi 1996).

In some instances, the impact on the poorest may in fact be negative. Paul Mosley and David Hulme 1996, surveyed "successful" microcredit programs in seven different countries. In all microcredit programs, the average earnings of borrowers increased. They also discovered that, the wealthier the borrower, the greater the income increases derived from credit. However, borrowers below the poverty line actually had lower incomes than before joining the programs, i.e., the poor actually became poorer through microcredit. The reasons for this are not clear. According to Mosley and Hulme 1996, the poor may use the loans 
differently, for consumption or to invest in lower risk (and generally less remunerative) activities. Meanwhile, the better-off borrowers tend to invest in riskier and more productive ventures, including technological improvements. The study concluded that "while credit may be an effective vehicle for boosting the incomes of the poor, it may be less effective, or even counter-productive, in helping the poorest of the poor raise their living standards. Alternative poverty reduction mechanisms are probably advisable for this group (Mosley and Hulme 1996). It has been observed that not only do the poorest borrowers benefit least, but most evidence also indicates the poorest $10-15$ per cent of the population are being altogether excluded from microcredit programs, and the poorest women face more barriers than men. A few studies have also been conducted to quantify the impact of microfinance on poverty alleviation. For instance, based on the counter factual combined approach, analyzed the impact of microfinance on poverty alleviation using sample data for Indonesia, India, Bangladesh and Sri Lanka and found that growth of income of borrowers always exceeds that of control group and that increase in borrowers income was larger for better-off borrowers (Mosley and Hulme 1996). Similarly MkNellyet al. (1996) found positive benefits for the borrowers. Khandker(1995), based on double difference comparison between eligible and ineligible households and between program and control villages, focusing on Grameen, Bangaladesh and Bangaldesh Rural Advancement Committee (BRAC), found that microcredit alleviated poverty up to 5 percent annually. Furthermore, it was found that a loan of Tk. 100.00 to a female borrower, after it is repaid, allows a net consumption increase of Tk. 18.00. For Thailand village banks, Coleman (1997), using the same approach as that of Khandker(1995), found no evidence of any impact of micro finance. Another study by Coleman (1997), found that programs are not reaching the poor as much as they reach relatively wealthy people. Khandker(1995), found that microfinance helps to reduce extreme poverty much more than moderate poverty, i.e. 18 percentage points as compared with 8.5 percentage points over seven years. Welfare impact is also positive for all households, including nonparticipants, as there were spillover effects. Mosley (1996), using data from Latin American countries, found a positive growth of income and assets of the borrowers than control group.

Bangladesh Government and Non-Government Organization (NGO) always try to alleviate the poverty. Many NGOs are providing microcredit to the poor people and they argued that poverty is alleviating day by day by taking microcredit (Hashemi et al 1996), (Bhattacharya, et al. 1996), (Hossain, M.,1988), (Khandker, S. R., 1998), (Yunus, M., 1999). 


\section{METHODOLOGY}

\section{Capacity Building and Transaction Power}

The term capacity means ability to do something. It can be defined as "activities which strengthen the knowledge, abilities, skills and behavior of individuals and improve institutional structures and processes such that the organization can efficiently meet its mission and goals in a sustainable way." (http://en.wikipedia.org/wiki/Capacity_building). Capacity building on an individual level states the development of conditions that allow individual to build and enhance existing economical condition. Transactions originate from the desire to exchange an asset or skill for product, service or another asset.

\section{Economic transaction power}

The economic transaction power involves the activities that generate and determine income (http://ssr1.uchicago.edu/NEWPRE/Orgs2/Williamson.html). In economic transaction power, the key concern is to assess the existing level of income generating process that may influence to overcome one's hardship. The various issues in the economic transaction are "the fixation process of wage rate of the laborer", "whether there is any payment for over time", "is there any sick allowance", "the price for selling their own product" and so on.

\section{Social transaction power}

The elements of social transactions are the activities that make an individual socially engaged (http://www.chacocanyon.com/pointlookout/120201.shtml). "Whether the poor get any invitation in social gatherings", "Do the poor have any membership of any local body?" "Are the opinion of the poor considered in case of rural development activities?" are the focal points to observe the social transaction power.

\section{Legal transaction power}

How well an individual is treated in the legal activities is the theme of legal transaction power. Legal transactions are the means by which an individual can ensure his right (JaapHage). In exploration of legal transaction power we will check "involvement in a case of quarrel in their life", "Settlement of quarrel", "court case likeliness" and "level of getting legal help". 


\section{Political transaction power}

Political awareness and freedom to think and support political activities are the power of political transaction (Fitts 1997). Voting tendency of the poor, choice in the voting activity, independence to give opinion in the political matter, pressure to take part in a political activity are the issues in the analysis of political transaction power.

\section{Government services}

A public service is a service which is provided by government to people living within its jurisdiction, either directly (through the public sector) or by financing private provision of services (http://en.wikipedia.org/wiki/Public_service). Among the distribution of government services, the important aspects are "possibility to get relief in odd days such as flood, cyclone, tornado etc", "availability of agricultural service such as fertilizer, pesticides, advance etc", "scope for use of Government land, water bodies etc".

\section{Target Population and Sample}

The target population of the study was the rural poor in the Laxmipur District. We selected respondent family whose monthly family income was not more than Tk. 6000.00. One of the main objectives of this research is to investigate the impact of microcredit for poverty alleviation. Hence, data were collected from 400 respondents, among them 280 (70\%) respondents who took microcredit is included in experimental group and others $120(30 \%)$ respondents who did not take microcredit is included in control group. Laxmipur district was purposively selected and the respondents are chosen using simple random sampling design. The data were collected between March 1, 2012 and March 31, 2012.

\section{Data Collection Technique}

The research program was designed to be qualitative and quantative in nature. The study used Focus Group Discussions (FGD), Participatory Rapid Appraisal (PRA) and Individual In-Depth Interviews. The team started with Focus Group Discussions, and then applied some of the PRA instruments. Once both the FGD and PRA had been completed, specific individuals were selected for in-depth interviews to enrich the data sets that had been developed. Upon completion of the data collection and documentation, each researcher was given a 
file of the complied data, and a series of meetings were held to compare, triangulate and interpret the results.

\section{DATA ANALYSIS}

\subsection{Characteristics of the respondents}

In the experimental group, data were collected form 280 respondents among them $185(66.1 \%)$ respondents were male and 95 (33.9\%) respondents were female. Among 280 respondents, age of the $35.7 \%$ of the respondent's lies between 30 and 40 and age of the $31.8 \%$ of the respondent's lies between 40 and 50 .

FIGURE 1(a-b):Gender and Age Distribution of the Respondents

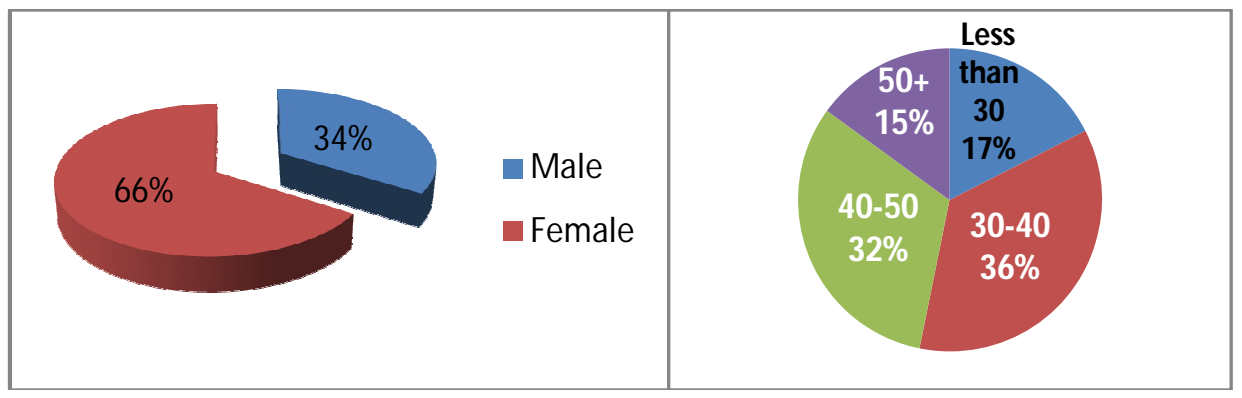

About half of the respondents said that their total family member is 4 or 5 . In our research, we observed that the family income of the $25 \%$ respondents is equal or less than Tk. 3000 per month and most of the family of respondents $(61.3 \%)$ have earned between TK. 3001 and Tk. 4500.00 per month. In economic transaction (table-3) power, only $7.5 \%$ of the respondents in experimental group got nationally determined wage rate (minimum daily wage Tk. 125.00). On other hand, about $61 \%$ of the respondents got market determined wage rate, where as about $31 \%$ of the respondents got the employer determined wage rate.

About $41 \%$ of the respondents said that they protested if their wage was smaller than market value or minimum wage rate and about $21 \%$ of the respondents did not protest in this issue because they have no alternative employment opportunity at that time. About $12 \%$ of the respondents did not protest because they did not dare to protest and about $26 \%$ respondent said that there is no benefit of protesting in this issue, that's why they did not protest. Only about $9 \%$ of the respondents got payment for over time, whereas about $56 \%$ of the respondents did not get payment for overtime and $37 \%$ got some tips or 
breakfast for overtime. Only 5\% of the co-workers got sick allowance if they are injured or sick due to work and about $75 \%$ of the co-worker did not get sick allowance but about $20 \%$ of the respondent said that they got partially sick allowance. About $38 \%$ of the respondent said that they did not get market price for selling their own product and they were compelled to sell at lower price than market price. Among this $38 \%$, about $35 \%$ of the respondent said that they were forced to sell at lower price because of advance sale of labor (no current demand for labor) and about 32\% said that they had no scope for preservation cell, that's why they were bound to sell at lower price.

TABLE 3

PERCENTAGE DISTRIBUTION OF SELECTED ECONOMIC TRANSACTION POWER

\begin{tabular}{lcc}
\hline \multicolumn{1}{c}{ Characteristics } & Respondent & \% \\
\hline Determination of wage rate & 21 & 7.5 \\
Nationally determined (daily Tk. 125) & 172 & 61.4 \\
Market determines & 87 & 31.1 \\
The employer determines & 116 & 41.4 \\
Action taken if wage is smaller than market value or minimum wage rate \\
Yes, I protest & 59 & 21.1 \\
No, as no alternative employment opportunity & 32 & 11.4 \\
No, Because, I do not dare to protest & 73 & 26.1 \\
No, Because, there is no benefit of protesting & & \\
Payment for overtime & 25 & 8.9 \\
it is paid & 157 & 56.1 \\
it is not paid & 98 & 37.0 \\
Some tips or breakfast is given & 14 & 5.0 \\
Any sick allowance from owner in case of injured or sick due to work & \\
Pay & 206 & 74.7 \\
Do not pay & 57 & 20.4 \\
Pay Partially
\end{tabular}

In social transaction characteristics (Table-4), only $28.6 \%$ of the respondents are invited in social gatherings such as marriage, milad, Eid festivals and so on, where as $22.5 \%$ of the respondents never invited in social gatherings. About $27 \%$ of the respondents said that they did not keep their assets such as cattle, goats, poultry, vegetables, garden etc. with other in case of their absence. About $15 \%$ of 
the respondents said that they did not keep their assets because of not trustworthy. About two third (75.4\%) of the respondents said that their opinion did not focus in case of rural development activities such as roads construction. Most of the respondents (95.6\%) said that they were not member of a local institution such as school.

In exploration of selected legal transaction power (Table-5), we observed that about $32 \%$ of the respondents ever involved in a case or quarrel in their life. Among them about $46 \%$ said that their rival was a powerful man in a society and about $40 \%$ of the respondents said that their rival was one like him. Among involved respondents in case, $58 \%$ of them moved into the court and about $28 \%$ of them solved by the help of the salish of villager. About $80 \%$ of the respondents, who involved cases, lost their property like cow/cattle or savings and $21.3 \%$ of the respondents lost their land for continuing case in court. And about $36 \%$ of the respondents said that they did not get market price and sold lower price from market price in case of selling their own property.

TABLE 4

PERCENTAGE DISTRIBUTION OF SELECTED SOCIAL TRANSACTION POWER

\begin{tabular}{lcc}
\hline \multicolumn{1}{c}{ Characteristics } & $\begin{array}{c}\text { Number of } \\
\text { respondent }\end{array}$ & \% \\
\hline $\begin{array}{l}\text { Are you invited in social gatherings (e.g., marriage, milad, Eid, } \\
\text { festivels) }\end{array}$ & 80 & 28.6 \\
Yes & 63 & 22.5 \\
No & 137 & 48.9 \\
Yes, invited occasionally & 69 & 24.6 \\
Any rural development activities (e.g., roads construction) sought & \\
Yes & 211 & 75.4 \\
No & 15 & 5.4 \\
Are you a member of a local body (e.g., School) & 265 & 94.6 \\
\hline Yes & No
\end{tabular}

In the analysis of political transaction power (Table-6), $55.7 \%$ of the respondents said that they can tell their own problems individually or jointly to the people's representative and about $23 \%$ of the respondents said that they never 
tell their problems to their representatives. About $7.2 \%$ of respondents said that they did not cast their vote because of no benefit.

TABLE 5

PERCENTAGE DISTRIBUTION OF SELECTED LEGAL TRANSACTION POWER

\begin{tabular}{lcc}
\hline Characteristics & $\begin{array}{c}\text { Number of } \\
\text { respondent }\end{array}$ & \% \\
\hline Were you ever involved is a case/quarrel in your life & & \\
No & 183 & 68.5 \\
Yes, it was land related & 29 & 10.9 \\
Yes, it was family affairs & 41 & 15.4 \\
Yes, it was others & 14 & 5.2 \\
A powerful man & 38 & 45.2 \\
One like me & 34 & 40.5 \\
A middle class man & 12 & 14.3 \\
If Yes, who was your rival & & \\
Help of salish was sought & 23 & 27.7 \\
You moved into the court & 48 & 57.8 \\
You solved the conflict yourself & 12 & 14.5 \\
Legal help & & \\
You moved the case at own cost & 12 & 18.2 \\
\hline
\end{tabular}

About $35 \%$ of the respondents said that they have a freedom in case of their opinion for against a political party, where as about $33 \%$ of the respondents said that they have no freedom and similar percent of the respondents said that they have to be careful in case their opinion for against a political party. About $44 \%$ of the respondent said that they have no freedom in case of opinion against a powerful man/woman.

On other hand, only $22.3 \%$ of the respondents said that they have a freedom in case of opinion against a powerful man/woman. About $30 \%$ of the respondents said that they have taken part in a political activity in their own interest. On other hand, about $22 \%$ of the respondents said that they have compelled to take part in a political activity in their own interest. 
Among the distribution of government services (table-7), $14.3 \%$ of the respondents never got relief in odd days such as flood, cyclone, tornado etc and $63.2 \%$ of the respondents said that they got relief occasionally in odd days; only $22.4 \%$ always got relief in odd days. About $64 \%$ of the respondents never got agricultural service such as fertilizer, pesticides, advance etc; only about $11 \%$ of the respondents have got these agricultural services regularly and about $25 \%$ of the respondents have got agricultural service occasionally. About $59 \%$ of the respondents said that the legal helps such as cooperation of police, processing of case were not available in the society. Only about $24 \%$ of the respondents said that these legal helps were available, where as $17.5 \%$ of the respondents said that these legal helps were not sufficient in the society. About two third of the respondents $(77.7 \%)$ said that there were no scope for use of government land, water, bodies etc.

TABLE 6

PERCENTAGE DISTRIBUTION OF SELECTED POLITICAL TRANSACTION POWER

\begin{tabular}{lcc}
\hline \multicolumn{1}{c}{ Characteristics } & $\begin{array}{c}\text { Number of } \\
\text { respondent }\end{array}$ & \% \\
\hline $\begin{array}{l}\text { You tell your problems to the people's representative } \\
\text { Yes }\end{array}$ & 156 & 55.7 \\
Occasionally & 60 & 21.4 \\
No & 64 & 22.9 \\
You cast your own vote & 260 & 92.9 \\
Yes & 3 & 1.1 \\
Not at all & 17 & 6.1 \\
$\quad$ No, because it has no benefit & & \\
You take part in a political activity in your won interest & 81 & 29.9 \\
take part spontaneously & 27 & 10 \\
Compelled to take part & 34 & 12.5 \\
$\quad$ do not take part because of ---fear & 91 & 33.6 \\
do not take part because of --- no benefit & 38 & 14 \\
$\quad$ do not take part because of --- no interest & & \\
\hline
\end{tabular}

In case of unhappiness, $88 \%$ of the respondents said that they did not draw the attention of the Government. And $11.6 \%$ of the respondents said that they did 
not dare to bring it to their notice and about $40 \%$ of the respondents said that they did not complain to notice of the Government because of no benefit.

TABLE 7

PERCENTAGE DISTRIBUTION OF GETTING GOVERNMENT SERVICES

\begin{tabular}{ccc}
\hline Characteristics & $\begin{array}{c}\text { Number of } \\
\text { respondent }\end{array}$ & \% \\
\hline Get Relief in odd days (flood, cyclone, tornado) & 61 & 22.4 \\
I get & 172 & 63.2 \\
I get occasionally & 39 & 14.3 \\
$\quad$ I do not get & & \\
I get & 13 & 10.8 \\
I get occasionally & 30 & 25 \\
$\quad$ I do not get & 77 & 64.2 \\
Scope for use of Govt. land, water bodies & & \\
$\quad$ I get & 42 & 22.3 \\
$\quad$ I do not get & 146 & 77.7 \\
\hline
\end{tabular}

\subsection{Impacts of Microcredit on poverty}

For understanding the impact of microcredit on poverty, we compared some characteristics of the poor people of experimental group with control group. The daily average family income of the experimental group was Tk. 182.00 and standard deviation was Tk. 78.00. In the contrast, the daily average family income of the control group was Tk. 165.00 and the standard deviation was Tk. 59.00. We observed that the average family income of the experimental group was larger than that of control group but which was not statistically significant differences $(t=1.936, d f=384, p$-value $=0.054)$ with $5 \%$ significance level.

There were no significant differences (table-8) of the situations between the microcredit lender and the people who did not take microcredit (say non microcredit lender) in case of the variables "any member of their family had to eat less during last month", "had taken fewer numbers of meals during the last one month", "had no food in their family and you had to eat by borrowing during last month" and "had no food available you or any other family member had to 
go to sleep with hungry". We have seen that there was significant difference between experimental and control group about the situation in the case of "did not have day long meals and had to go to bed with hunger because of nonavailability of food".

\section{TABLE 8}

\section{COMPARISON ABOUT FOOD SECURITY BETWEEN EXPERIMENTAL GROUP AND CONTROL GROUP}

\begin{tabular}{lllllc}
\hline Category & \multicolumn{1}{c}{$\begin{array}{l}\text { Taking } \\
\text { Microcredit }\end{array}$} & $\begin{array}{l}\text { Not taking } \\
\text { microcredit }\end{array}$ & $\begin{array}{l}\text { Decision } \\
\text { at 5\% } \\
\text { level }\end{array}$ \\
\hline & Yes & No & Yes & No & $\begin{array}{l}\text { proportion } \\
\text { test }\end{array}$ \\
\hline $\begin{array}{l}\text { You had not enough food } \\
\text { during last month }\end{array}$ & $82.9 \%$ & $17.1 \%$ & $77.5 \%$ & $22.5 \%$ & NS \\
\hline $\begin{array}{l}\text { You had fewer number of } \\
\text { meal last month }\end{array}$ & $76.4 \%$ & $23.6 \%$ & $71.7 \%$ & $28.3 \%$ & NS \\
\hline $\begin{array}{l}\text { You had to eat by } \\
\text { borrowing }\end{array}$ & $75.0 \%$ & $25.0 \%$ & $66.7 \%$ & $33.3 \%$ & NS \\
\hline $\begin{array}{l}\text { Family member had to go } \\
\text { to sleep hungry }\end{array}$ & $61.3 \%$ & $38.7 \%$ & $50.8 \%$ & $49.21 \%$ & $\mathrm{NS}$ \\
\hline $\begin{array}{l}\text { Family member did not } \\
\text { have day long meals and } \\
\text { had to go to bed in hunger }\end{array}$ & & & & & $\mathrm{S}$ \\
\hline
\end{tabular}

Note: NS means Non Significant, S means Significant

We compared previous 5 years situation (Table-9), and observed that food security of the people of both groups have been improved. But this improvement was not statistically significant between microcredit borrower and non microcredit borrower in case of about "less eating in a day", about "no food in family so that had to eat by borrowing", about "no food in family so that had to go to bed with hunger", about "no food in family so that had to pass a whole day with hunger". We got significant differences in the case of the situation about taking fewer numbers of meals and in that case, the non-microcredit borrower improved more than that of microcredit borrower. 
TABLE 9

SITUATION ABOUT FOOD SECURITY BETWEEN EXPERIMENTAL AND CONTROL GROUP DURING LAST 5 YEARS

\begin{tabular}{llllll}
\hline Category & $\begin{array}{l}\text { Taking } \\
\text { Microcredit }\end{array}$ & $\begin{array}{l}\text { Not } \\
\text { microcredit }\end{array}$ & $\begin{array}{l}\text { taking } \\
\text { Decision } \\
\text { level }\end{array}$ \\
\hline $\begin{array}{l}\text { 5\% } \\
\text { His your situation (about }\end{array}$ & Better & Worse & Better & Worse & $\begin{array}{c}\text { proportion } \\
\text { test }\end{array}$ \\
eating less) improved or \\
worsened during the last 5 \\
years?
\end{tabular}

Note: NS means Non Significant, S means Significant 


\subsection{Bivariate Analysis}

From bivariate analysis (Table-10), we observed that the monthly family income was significantly associated ( chi square $=89.08, \mathrm{p}-$ value $=0.002$ ) with the variable "determination of wage rate". By directional measure, we found (eta $=0.230$ when monthly family income was dependent, eta $=0.405$ when determination of wage rate was dependent) that both variables were highly significant for changing one to another. We also observed that the monthly family income was significantly associated with protesting capability about less wage from minimum wage rate (chi square $104.1, \mathrm{p}$-value $=0.043$ ) and by directional measure, we found monthly family income was significant (eta = 0.234 when monthly wage was dependent, eta $=0.326$ when protesting capability about less wage from minimum wage rate was dependent) for changing one to another.

TABLE 10

TESTING THE ASSOCIATION BETWEEN MONTHLY FAMILY INCOME WITH OTHER VARIABLES

\begin{tabular}{lllll}
\hline Variables & $\begin{array}{l}\text { Value of } \\
\text { Chi-Square }\end{array}$ & $\begin{array}{l}\text { P- } \\
\text { value }\end{array}$ & Decision \\
\hline $\begin{array}{l}\text { Monthly family Income vs. } \\
\text { Determination of wage rate }\end{array}$ & 89.08 & 0.002 & Significant \\
\hline $\begin{array}{l}\text { Monthly family Income vs. Do you } \\
\text { protest if your wage is smaller than } \\
\text { market value or minimum wage rate }\end{array}$ & & 0.043 & Significant \\
$\begin{array}{l}\text { Monthly family Income vs. Payment } \\
\text { for overtime }\end{array}$ & 92.05 & 0.001 & Insignificant \\
\hline $\begin{array}{l}\text { Monthly family Income vs. sell } \\
\text { product (at market price or compelled } \\
\text { to sell to other at lower price than } \\
\text { market price) }\end{array}$ & & & \\
\hline $\begin{array}{l}\text { Monthly family income vs. In case } \\
\text { you yourself cultivate your land, then } \\
\text { in comparison to larger farmers you } \\
\text { get irrigation and seeds }\end{array}$ & & 0.009 & Insignificant \\
\hline
\end{tabular}




\subsection{Multiple Regression Analysis}

Regression analysis is a powerful and widely used statistical tool for the investigation of relationships between variables. Usually, the causal effect of one or more variables upon another is observed. To explore such issues, regression is employed to estimate the quantitative effect of the causal variable upon the variables that they influence. Typically, it is assessed the "statistical significance" of the estimated relationships, that is, the degree of confidence that the true relationship is close to the estimated relationship. We wish to identify and quantify the contribution of the determinants that influence income to the rural poor. A moment's reflection suggests a myriad of elements that are associated with variations in income across individuals-occupation, age, educational attainment, race and gender.

In our study we investigate some variables to identify the significance on income. The response variable is average monthly income of the respondent's family. The predictor variables are like age of the main income earner, gender (Female-0, Male-1), size of the family, micro-credit taking status (No-0, Yes-1), wage rate fixation process (Employee-0, Market-1), other income source availability (No-0, Yes-1) wage payment method (Hourly basis-0, daily basis-1). The predictor variables are chosen after reviewing the literature and personal logical judgment. Multiple regression analysis is done to model the relationship between response variable and predictor variables. The stepwise regression is employed to choose the relevant important variables. The analysis is done through SPSS 20.0 version. The ANOVA states that the impact of the variables included in the model are not all statistically insignificant $(\mathrm{F}=15.798, \mathrm{p}=0.000)$.

\section{TABLE 11 \\ SIGNIFICANCE OF REGRESSION CO-EFFICIENTS (ANOVA)}

\begin{tabular}{lrrrrr}
\hline Model & Sum of Squares & \multicolumn{1}{c}{ df } & Mean Square & F & P-value \\
\hline Regression & 163912914.646 & 4 & 40978228.661 & 15.798 & .000 \\
Residual & 1019414333.652 & 393 & 2593929.602 & & \\
Total & 1183327248.298 & 397 & & & \\
\hline
\end{tabular}

The stepwise regression analysis in each step chooses the most significant variable and the process continues as long as it finds significant variables. The final model correctly specifies $57 \%$ of the variation of the income. We find that the final model in the stepwise regression is significant with the variables wage rate fixation process, size of the family, gender and micro-credit taking status. 
TABLE 12

ESTIMATES OF REGRESSION COEFFICIENTS

\begin{tabular}{|c|c|c|c|c|c|c|}
\hline \multirow[t]{2}{*}{ Model } & \multicolumn{2}{|c|}{$\begin{array}{c}\text { Unstandardized } \\
\text { Coefficients }\end{array}$} & \multirow{2}{*}{$\begin{array}{c}\begin{array}{c}\text { Standardized } \\
\text { Coefficients }\end{array} \\
\text { Beta }\end{array}$} & \multirow[t]{2}{*}{$\mathrm{t}$} & \multirow[t]{2}{*}{$\begin{array}{c}\mathrm{P}- \\
\text { value }\end{array}$} & \multirow[t]{2}{*}{$\mathrm{R}^{2}$} \\
\hline & B & Std. Error & & & & \\
\hline (Constant) & 2598.952 & 274.937 & & 9.453 & .000 & \multirow{5}{*}{.578} \\
\hline $\begin{array}{l}\text { Determination of } \\
\text { wage rate }\end{array}$ & 832.140 & 184.822 & -.216 & -4.502 & |000 & \\
\hline Size of the family & 205.783 & 53.528 & .183 & 3.844 & .000 & \\
\hline Gender & 599.308 & 178.410 & .165 & 3.359 & .001 & \\
\hline Taking microcredit & 569.081 & 179.847 & .151 & 3.164 & .002 & \\
\hline
\end{tabular}

The final model depicts that average monthly income is Tk. 832.14 more if the wage rate is determined by market rather than employee considering all the effects of other variables constant. The study certifies that Male individual earns more than female. It also undertakes that individual who takes micro-credit earns more. An interesting and important finding is that on the average monthly income of the family with higher of members is higher than the family with relatively less number of members.

\section{CONCLUSION}

We observed that poor people are mostly deprived of all transaction powers such as economical, social, legal, political facilities from Government. Only $7.5 \%$ of the respondents got nationally determined wage rate which was minimum daily wage Tk. 125.00 in 2011 and people did not want to protest against the less wage rate. About $56 \%$ of the respondents did not get payment for overtime where as $37 \%$ got some as tips and about $75 \%$ of the worker did not get sick allowance if they are injured or sick due to work. The social bond between the poor and the rich is very weak which results into insecurity. Governmental body or the rich people have always avoided their opinion for rural development activities. About $22.5 \%$ of the respondents have never been invited in social gatherings. The poor did not get legal support properly and they lost everything if they involve in court case. At that time, they sell their property at lower price. Another important observation is that about $23 \%$ of the respondents said that they never tell their problems to their representatives such as Chairman, Member etc. Some of the people (7.2\%) said that they did not cast their vote because of no 
benefit. About $44 \%$ of the respondents said that they have no freedom in case of giving opinion against a powerful man/woman. The poor people are greatly deprived of politically; about $22 \%$ of the respondents said that they are compelled to take part in a political activity. They are also deprived of getting the Government facilities. About $14.3 \%$ of the respondents never got relief in odd days such as flood, cyclone, tornado etc. About $64 \%$ of the respondents never got agricultural services such as fertilizer, pesticides, loan and advance. We investigated that microcredit has no significant effect on poverty alleviation. The situation of the poor people was not significantly changed who take microcredit. From focus group discussion, they faced in vicious circle in case of poverty. So, we need to ensure all transactional powers of the poor people because of individual transacting powers are vital points of poverty alleviation. The proper distribution of Government facilities plays an important role for eradicating poverty. And we should remove all discrimination for providing Government facilities; hence the poverty is related with individual powers of transactions and distribution of Government facilities.

\section{REFERENCES}

Carr, M, Martha C and Renana J (1996). Speaking Out: Women's Economic Empowerment in South Asia,London: IT Publications, 1996.

Coleman, B. E. (1999). The Impact of Group Lending in Northeast Thailand, Journal of Development Economics, Volume 60, pp.105-141.

Fitts, Michael A (1997). The Foibles of Formalism: Applying a Political 'Transaction Cost' Analysis to Separation of Powers,Case Western Reserve Law Review, Summer97, Vol. 47 Issue 4, p1643, 8p.

Gordon, D. (2011). Indicators of Poverty \& Hunger, United Nations, Retrieved 2011-05-27.

Hashemi, S. M., and S. R. Schuler, et al. 1996. Rural Credit Programs and Women's Empowerment in Bangladesh.WorldDevelopment24(4): 635653.

Hashemi, S.M., S.R.Schuler, and A.P. Riley. Rural Credit Programs and Women's Empowerment in Bangladesh,World Development, Vol. 24, Number 4, April 1996, pp.635-653.09

Hossain, M.,1988. Credit for Alleviation of Rural Poverty: The Grameen Bank in Bangladesh, Research Report, 65, IFPRI, Washington, D.C. 
http://en.wikipedia.org/wiki/Poverty_in_Bangladesh

Hulme, D., D. Bhattacharya, et al. 1996. Credit for the Poor in Bangladesh: The BRAC Rural Development Programme and the Government Thana Resource Development and Employment Programme,Finance against Poverty, Hulme, D. and. P. Mosley, Routledge, London. Vols. 1 and 2.

Hulme, David and Paul Mosley. Finance Against Poverty, London: Routeledge, 1996.

JaapHage, What is a legal transaction? http://www.academia.edu/.

Khandker, S. R. and BaquiKhalily. Designing a Sustainable Poverty Alleviation Program: The BRAC Strategy in Bangladesh. (Paper prepared for a workshop on "Credit Programs for the Poor" held in Dhaka, March 1995), The World Bank and the Bangladesh Institute of Development Studies, 1995.

Khandker, S. R., 1998. Micro-credit Program Evaluation: A Critical Review, IDS Bulletin 29(4), 11-20.

Khandker, S. R., B. Khalily and Z. Khan, 1995.Grameen Bank, Performance and Sustainability, World Bank Discussion Papers 306.

MKNelly, B., C. Watetip, C. A. Lassen and C. Dunford (1996). Preliminary Evidence that Integrated Financial and Educational Services can be Effective against Hunger and Malnutrition. Freedom from Hunger Research Paper No. 2, Freedom from Hunger, April.

Sen, G., 1997. Empowerment as an Approach to Poverty, Human Development Report, Background Paper (New York: The UNDP) 96-97.

World Bank 1994. The World Bank's Strategy for Reducing Poverty and Hunger, Environmentally Sustainable Development Studies, Monograph $\operatorname{series(No.4):3.~}$

Yunus, M., 1999.Banker to the Poor, The Autobiography of Muhammad Yunus, Founder of the Grameen Bank. Aurum press limited. London.

Zweig, Michael, 2004.What's Class Got to do With It, American Society in the Twenty-first Century. ILR Press. ISBN 978-0-8014-889-3 
